\title{
Myocarditis suggesting acute myocardial ischemia, without occlusion of the coronary artery, in a patient with antiphospholipid syndrome and systemic vasculitis in the course of cold agglutinin disease
}

\author{
Andrzej J. Sałacki, Andrzej P. Wysokiński
}

Chair and Department of Cardiology, Medical University of Lublin, Lublin, Poland

Submitted: 15 April 2016

Accepted: 7 May 2016

Arch Med Sci Atheroscler Dis 2016; 1: e32-e35

DOI: 10.5114 /amsad.2016.60026

Copyright (c) 2016 Termedia \& Banach

Myocarditis $(\mathrm{MCl})$ is a disease which continually challenges contemporary cardiology because of its clinical course, diagnostic difficulties and lack of effective therapy [1]. By definition, it is an inflammation of the heart muscle including myocytes, interstitial tissue and blood vessels. It is difficult to determine the incidence of $\mathrm{MCl}$ because endomyocardial biopsy, the gold diagnostic standard [2, 3], is rarely performed. The most common cause of $\mathrm{MCl}$ is viral infection [4]. Adenoviruses and enteroviruses are the most common viruses in Europe, and in recent years the prevalence of parvovirus B19 and human herpesvirus 6 (HHV-6) has been increasing [5-7].

We present a case of a 67-year-old patient who was transferred from an Infectious Diseases Clinic, where he was to be observed to diagnose hepatitis C due to suspected ST-elevation myocardial infarction (STEMI) after taking an ECG recording upon admission to the cardiac intensive care unit (CICU). His medical history showed ischaemic brain stem stroke, left hemiparesis, systemic vasculitis and chronic anaemia in the course of cold agglutinin disease, resolved meningitis, mediastinal lymphadenopathy, his condition after several bouts of pneumonia and laparotomy carried out due to intestinal obstruction, suspected lymphoma of the central nervous system and recognized antiphospholipid syndrome, as well as hypertension, hypercholesterolaemia, his condition after myocardial infarction of the inferior-lateral wall with percutaneous right coronary artery intervention and implantation of a drug-eluting stent in 2009. A few months ago the patient suffered from central pulmonary embolism as a result of venous thrombosis of the right lower limb.

Upon admission: blood pressure $110 / 82 \mathrm{~mm} \mathrm{Hg}$, single symmetrical crackles heard at the lung base, enlarged liver, peripheral oedema, acrocyanosis of the tip of the nose and the ears, as well as livedo reticularis all over the body, without pain in the thorax. The ECG showed sinus tachycardia 110/min, ST-segment elevations in leads I > II, aVL, aVF, V2-V6, with the PQ lowered in lead I and elevated in lead aVR, ST-segment depression in leads III and aVR (Figure 1). The laboratory tests showed right blood count (RBC) $2.86 \times 10^{6} \mathrm{cells} / \mu \mathrm{l}$, haemoglobin (HGB) $9.9 \mathrm{~g} / \mathrm{dl}$, heamatocrit (HCT) 29.5\%, mean corpuscular volume (MCV) $103.1 \mathrm{fl}$ and C-reactive protein (CRP) $42 \mathrm{mg} / \mathrm{l}$, BNP $1548 \mathrm{pg} / \mathrm{ml}$, troponin I > $50 \mathrm{ng} / \mathrm{ml}$ (standard: $<0.04 \mathrm{ng} / \mathrm{ml}$ ), glomerular filtration rate (GFR) $62 \mathrm{ml} / \mathrm{min} / 1.73 \mathrm{~m}^{2}$, activated partial thromboplastin Time (APTT) extended to $45 \mathrm{~s}$.

\author{
Corresponding author: \\ Andrzej J. Sałacki \\ Chair and Department \\ of Cardiology \\ Medical University of Lublin \\ 8 Jaczewskiego St \\ 20-954 Lublin, Poland \\ Phone: +48606353311 \\ E-mail: andrzejxx17@wp.pl
}


While in the CICU, the patient was diagnosed with STEMI and then directed to have coronary angiography (Figures 2, 3) performed. Before the examination the patient was given $600 \mathrm{mg}$ of clopidogrel, $300 \mathrm{mg}$ of acetylsalicylic acid and $5000 \mathrm{U}$ of heparin by intravenous bolus. The results showed that the patient had a borderline constriction in the middle/distal right coronary artery (RCA), insignificant constriction of the outlet of the left coronary artery trunk, a 30\% constriction in the distal segment, a significant constriction in the proximal/middle left anterior descending (LAD) segment, significant stenosis in the bifurcation of the first marginal branch in the proximal segment of the circumflex branch, and significant stenosis in its outlet. After cardiac surgery consultation the patient was qualified for conservative treatment. Transthoracic echocardi- ography showed massive hypokinesis of the left ventricle (LV), especially of the apical region, with massive hypertrophy, 24\% left ventricle ejection fraction (LVEF), as well as fluid in the pericardium up to $2 \mathrm{~cm}$ behind the LV rear wall. On the next day, in the $\mathrm{CICU}$, the patient had a cardiac arrest with asystole. The patient died.

The basic recognized problem was myocarditis $(\mathrm{MCl})$, although STEMI was suspected at first and the patient was treated in accordance with this diagnosis. That diagnosis was supported by the maximum increase of troponin I in five assays and the ECG features suggesting acute ischemia-wave STEMI [8]. Figures 4-5 present further ECGs taken at intervals. Arguments to the contrary included the angiographic picture excluding the possibility of occlusion of the coronary vessel, lack of changes to the ST-segment elevation in the ECG record-

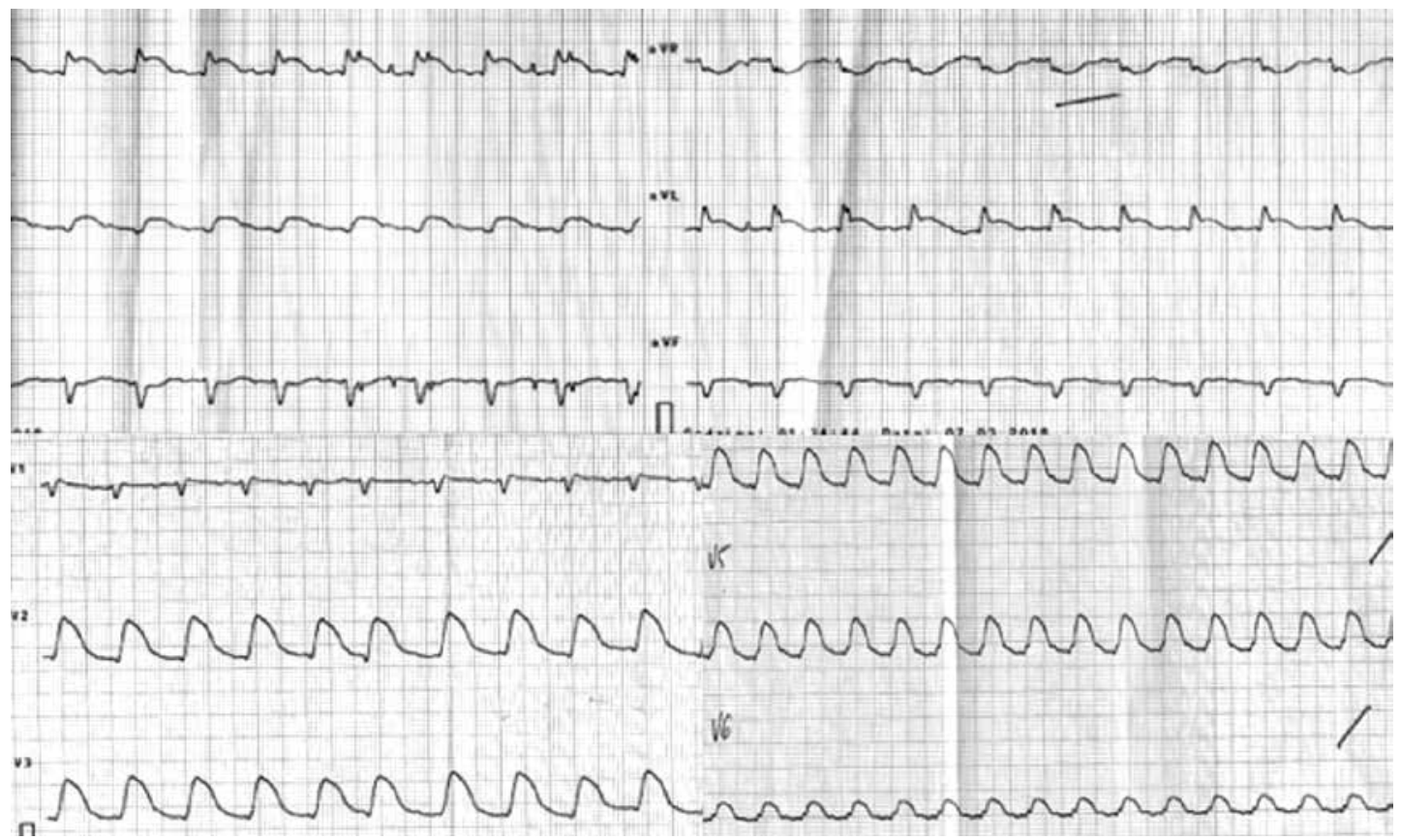

Figure 1. ECG upon admission

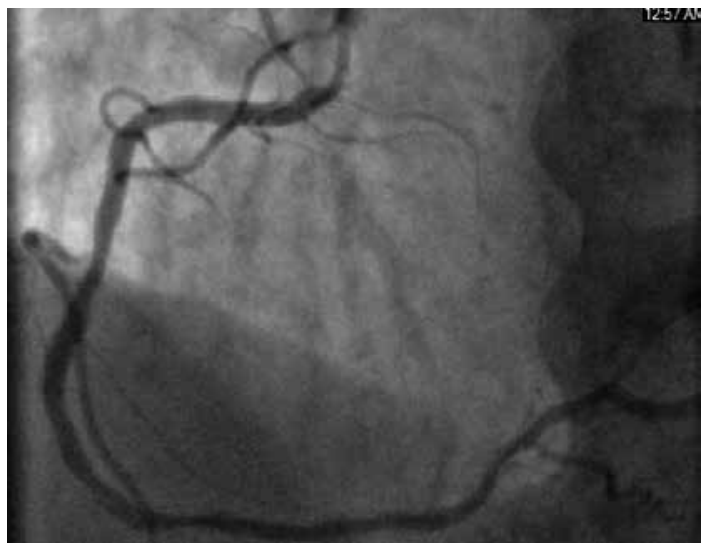

Figure 2. Borderline constriction in the middle/distal RCA

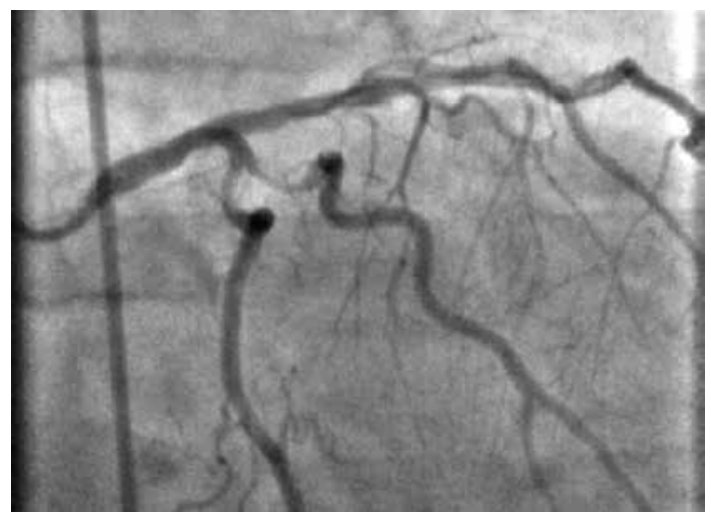

Figure 3. Significant constriction in the proximal/ middle LAD segment 


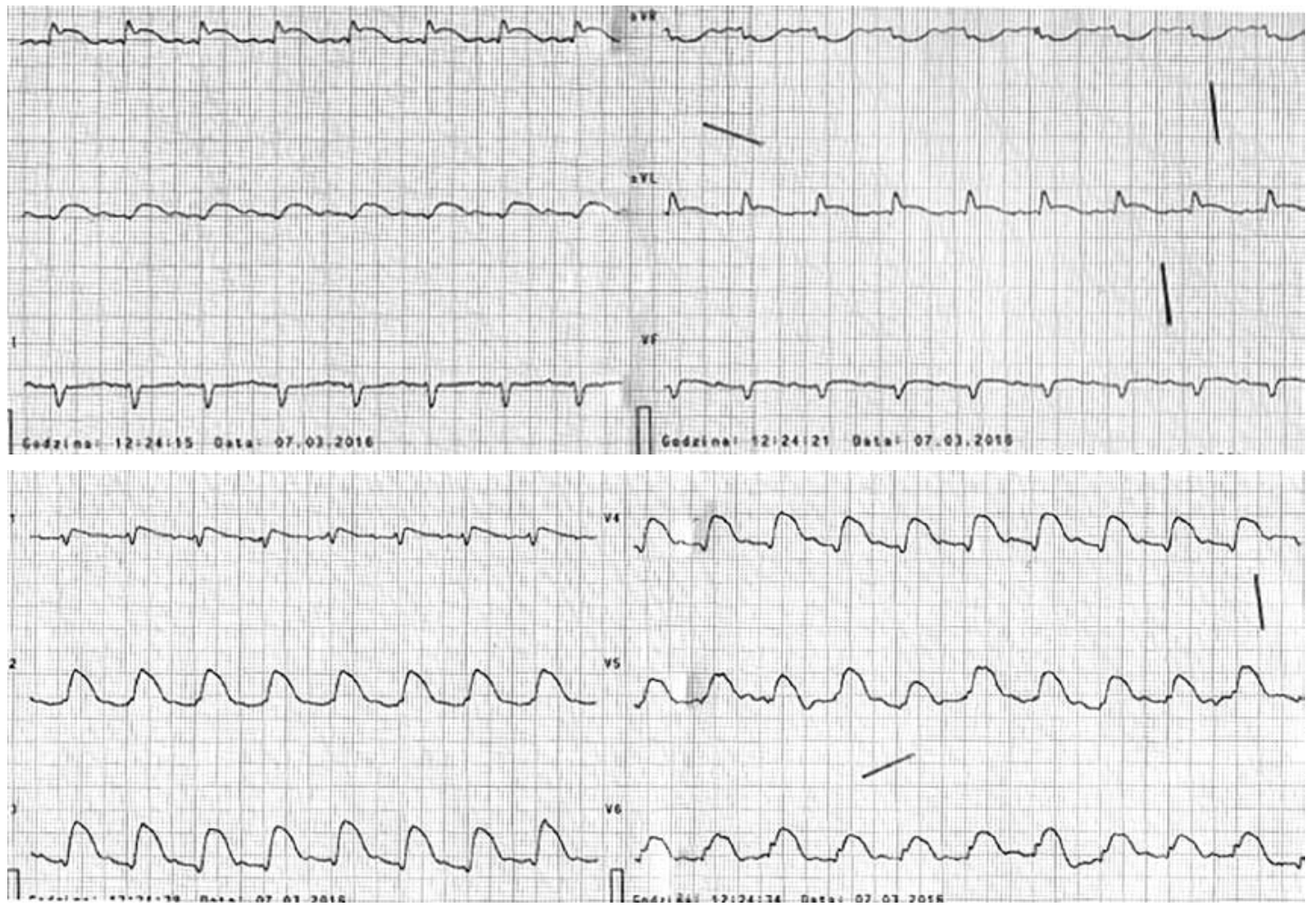

Figure 4. ECG taken $10 \mathrm{~h}$ after admission (sinus rhythm 100/min, ST-segment elevations in leads I > II, aVL, aVF, V1-V6, with the PQ shortened, ST-segment depression in lead aVR)

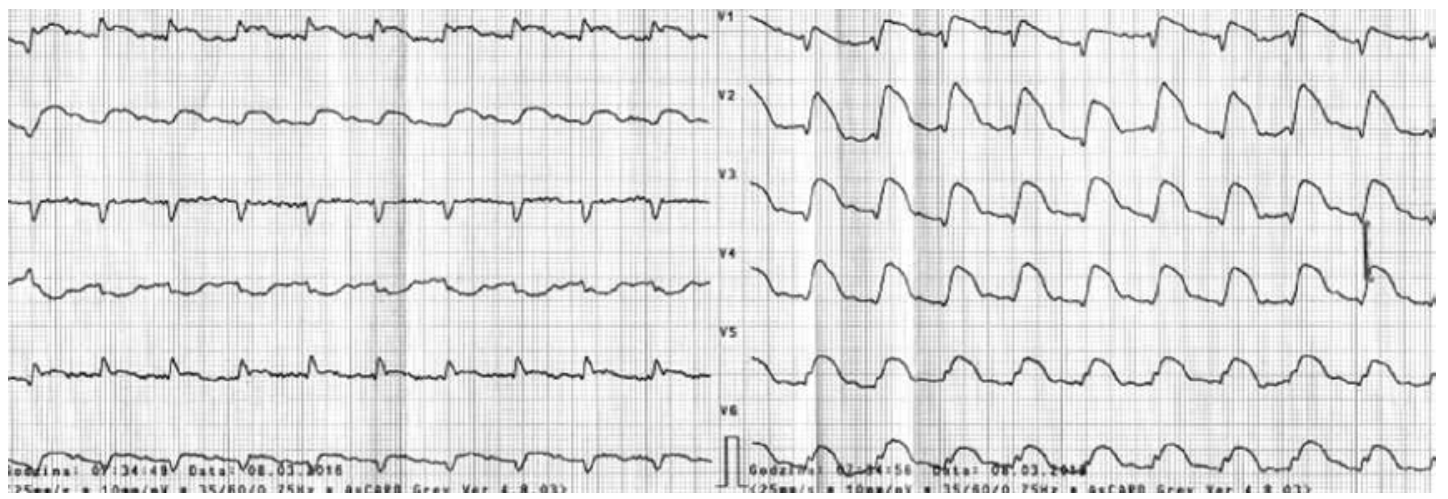

Figure 5. ECG taken $29 \mathrm{~h}$ after admission (sinus rhythm 95/min, ST-segment elevations in leads I, II, aVL, aVF, V1-V6, with the PQ shortened. ST-segment depression in lead aVR)

ing and no pain in the thorax for the whole period of hospitalization in the CICU.

Arguments supporting $\mathrm{MCl}$ included raised CRP level and increased troponin I, though the patient did not suffer from high temperature or leukocytosis during his stay, contraction dysfunction of the LV, fluid in the pericardium, as well as changes to the ECG - ST-segment elevations in leads I > II, $\mathrm{aVL}, \mathrm{aVF}, \mathrm{V} 2-\mathrm{V} 6$, with the PQ interval shortened and lowered in lead I and elevated in aVR, ST-segment depression in aVR with ST-segment raised in leads I and II [9-11] at the same time - a valuable symptom, yet very often omitted in differential diagnosis between STEMI and $\mathrm{MCl}$. Damage to the $\mathrm{LV}$ in $\mathrm{MCl}$ might be divided into two different types, depending on the virus. The first type with characteristics of myocardial infarction is typical in the case of PVB19 infection. This virus does not damage myocytes, but infects and damages endothelial cells of the microcirculation vessels. Damage to the myocardium is caused through ischaemia and inflammation; thus it explains the release of troponin and electrographic features of myocardial infarction. The other type of damage can be found in half of the HHV- 6 cases and the majority of PVB19 cases. It is characterized by subacute heart failure symptoms. ECG often shows the presence of bundle branch block. The mechanism of damage to the LV is not fully known yet. The HHV- 6 virus is related to nerve cells, in - 
cluding cardiac cells of the conduction system. The placement within the interventricular septum may be connected with the proximity to the conduction system which, if affected, causes bundle branch block [12].

In conclusion, the present case indicates that $\mathrm{MCl}$ might manifest itself as STEMI. It should be noted that in every case of suspected STEMI, MCl needs to be taken into consideration in the differential diagnosis.

\section{Conflict of interest}

The authors declare no conflict of interest.

\section{References}

1. Spinczyk B, Warmusz-Reichman E, Wojnicz R, Poloński L. Myocarditis. Choroby Serca i Naczyń 2011; 8: 124-31.

2. Richardson P, McKenna W, Bristow M, et al. Report of the 1995 World Health Organization/International Society and Federation of Cardiology Task Force on the Definition and Classification of cardiomyopathies. Circulation 1996; 93: 841-2.

3. Zapolski T, Haratym-Zwolak A, Wysokiński A. Współczesne zasady diagnostyki zapalenia mięśnia sercowego i kardiomiopatii pozapalnej. Folia Cardiologica 2015; 10: 259-67.

4. Kukla P, Bryniarski L, Bromblik A, Szczuka K, KaweckaJaszcz K. Myopericarditis przebiegające ze wstrząsem kardiogennym i obrazem klinicznym zawału ściany dolnej u mężczyzny z nadczynnością tarczycy i cukrzycą. Kardiol Pol 2008; 66: 982-6.

5. Kuhl U, Pauschinger $M$, Noutsias $M$, et al. High prevalence of viral genomes and multiple infections in the myocardium of adults with "idiopathic" left ventricular dysfunction. Circulation 2005; 111: 887-93.

6. Marholdt H, Wagner A, Deluigi C, et al. Presentation, patterns of myocardial damage, and clinical course of viral myocarditis. Circulation 2006; 114: 1581-90.

7. Yilmaz A, Marholdt H, Athanasiadis A, et al. Coronary vasospasm as the underlying cause for chest pain in patients with PVB19 myocarditis. Heart 2008; 94: 1456-63.

8. Pardee HEB. An electrocardiographic sign of coronary artery obstruction. Arch Intern Med 1920; 26: 244-57.

9. Achremczyk P, Janiec A, Duda K. Przedłużony ból wieńcowy z uniesieniem odcinka ST w EKG i gorączką - leczyć fibrynolitycznie czy myśleć o zapaleniu mięśnia sercowego. Kardiol Pol 2002; 56: 629-33.

10. Nessler J, Libionka A, El Massri N, et al. Acute coronary syndrome or perimyocarditis? A case report. Kardiol Pol 2004; 61: 571-3.

11. Dąbrowska B. Komentarz do pracy: Achremczyk P, Janiec A, Duda K. Przedłużony ból wieńcowy z uniesieniem odcinka ST w EKG i gorączką - leczyć fibrynolitycznie czy myśleć o zapaleniu mięśnia sercowego. Kardiol Pol 2002; 56: 635.

12. Mahrholdt H, Wagner A, Deluigi C, et al. Presentation, patterns of myocardial damage, and clinical course of viral myocarditis. Circulation 2006; 114: 1581-90. 